\title{
Resources in NPD: An Investigation of Resource Capabilities
}

\author{
Sanjay R. Sisodiya ${ }^{1} \&$ Jean L. Johnson ${ }^{2}$ \\ ${ }^{1}$ College of Business and Economics, University of Idaho, USA \\ ${ }^{2}$ College of Business, Washington State University, USA \\ Correspondence: Sanjay R. Sisodiya, College of Business and Economics, PO Box 443161, Moscow ID USA \\ 83844, USA. Tel: 1-208-885-0267. E-mail sisodiya@uidaho.edu
}

Received: October 31, 2013

Accepted: January 7, $2014 \quad$ Online Published: January 22, 2014

doi:10.5539/ijbm.v9n2p103

URL: http://dx.doi.org/10.5539/ijbm.v9n2p103

\begin{abstract}
In this paper we examine the role of resources in improving new product process outcomes. We propose a model where resource flexibility and augmentation serve as mechanisms to identify and accumulate resources that increase the firm's ability to respond to opportunities and challenges in the new product development process. Important to the development of this resource base is the need to also leverage accumulated resources. Thus, the model is further developed to incorporate the role of resource leveraging as a moderator to the resource base and performance link. Using a cross-industry sample, a series of hypotheses are tested to evaluate the moderating role of resource leveraging on the link between a firm's resource base and its performance. Results suggest that resource flexibility and augmentation improves new product outcomes, and that resource leveraging can lead to enhanced performance.
\end{abstract}

Keywords: resource-based view, new product development, speed, cost

\section{Introduction}

Nearly half of firms' sales and profits come from products launched within the previous five years (Schmidt \& Calantone, 2002), which implies that product innovation is key to firm success (Henard \& Szymanski, 2001; Hsu, 2011). Because product development exerts such a strong effect on firm profitability (Ersun \& Karabulut, 2013), research on new product development (NPD) continues to be of interest. For a firm to innovate, it must focus on resources and capabilities that facilitate its enhanced NPD (Kandemir, Calantone, \& Garcia, 2006; Rumelt, 1987). Therefore, to explore the effects of such resources and capabilities on NPD, we consider the NPD process outcomes of speed and cost. Project speed refers to the time required to complete specific phases of the NPD process, from project conceptualization and initiation to product commercialization; process costs are those associated with various phases of NPD, including expenditures in support of development and commercialization.

Both speed and cost might depend on the various levels of technology and intellectual property that firms have at their disposal to develop products. For example, resource flexibility, or the ability to deploy resources (Johnson, Lee, Saini, \& Grohmann, 2003; Sanchez, 1995), enables firms to apply their resources in various new product projects. To succeed, firms also must constantly seek to expand their limited base of resources through resource augmentation, which is a process of developing and expanding a resource base. Resource flexibility and augmentation may not be sufficient for a firm to complete NPD projects though; managers likely need to use their resource bases more effectively (Calantone, Harmancioglu, \& Droge, 2010). Thus, we also consider resource leveraging, or the ability of the firm to use resources to its benefit, as a critical capability for attaining access to resources and then using them appropriately (Sirmon \& Hitt, 2003).

Extant literature provides little information about project costs or speed in the context of such resource characteristics and capabilities though. Because resources play such a critical role in the NPD process, a lot remains to be learned. To contribute to this line of research, we explore relationships among resource flexibility, resource augmentation, resource leveraging, and NPD process outcomes (see Figure 1). We outline our conceptual background next, pertaining to resource characteristics and capabilities, then discuss the conceptual model and our hypotheses. After we test our proposed model, we discuss the results and their implications for both research and practice. 


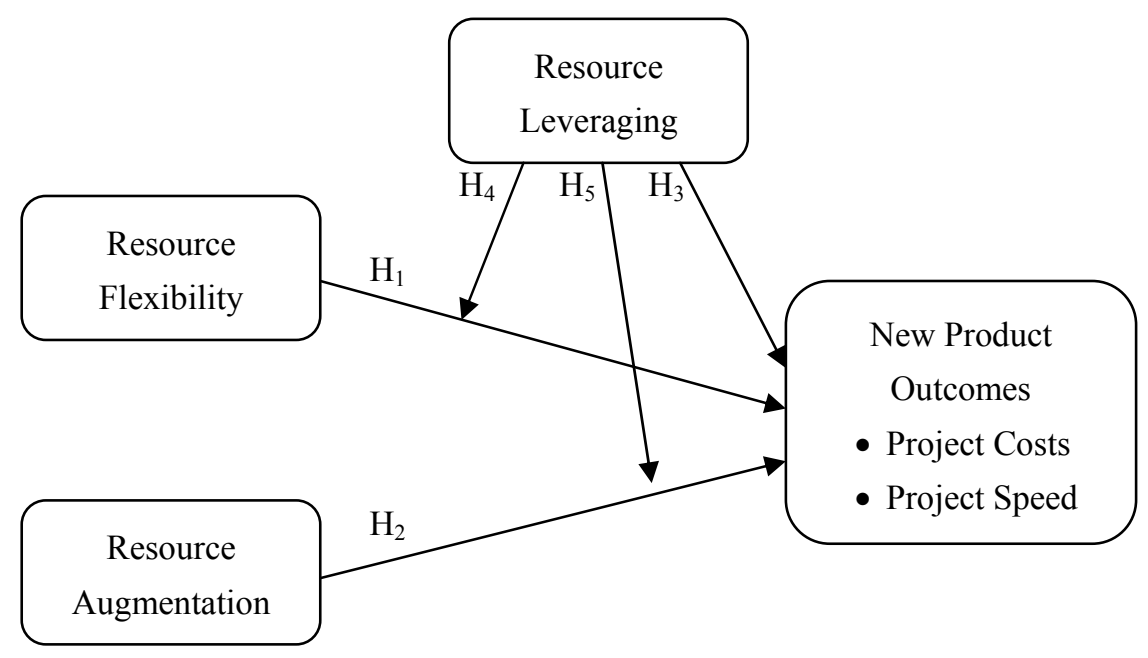

Figure 1. Resource leveraging as a moderator

\section{Conceptual Background and Model Development}

Successful NPD is among the most challenging, and most critical, outcomes to manage, because it requires both advance planning and quick decisions in constantly changing markets (Kessler \& Bierly, 2002). Because the process outcomes of NPD occur earlier than product outcomes (Griffin, 1993), managers often use them for project comparisons. Shortening product life cycles also lead to increased emphases on the process of product innovation. Thus, we investigate the outcomes of cost and speed.

\subsection{Cost}

Cost reduction strategies in NPD vary widely and may include process changes (Griffin, 1997), which managers adopt to gain advantages over rivals, in the hope that these changes will affect their market share, profitability, and long-term competitiveness (Sanchez \& Perez, 2003). As Griffin (1993) notes, project costs consist of NPD development and commercialization costs. Good projects typically come in at or below projected costs; bad projects exceed projected cost estimates (Schmidt \& Calantone, 1998). During the development phase, expenditures begin, and then the commercialization stage creates manufacturing and product launch costs (Griffin, 1997). There also might be a trade-off between development costs and the time needed to develop products (Bayus, 1997). The rate at which products get developed thus represents an effective measure of NPD performance.

\subsection{Speed}

In product development research, innovation speed is one of the least studied factors (Montoya-Weiss \& Calantone, 1994), despite its importance (Langerak \& Hultink, 2006). The speed at which products get developed is vital for managing NPD, because of the ever increasing demand to shorten development cycles (Kessler \& Bierly, 2002; Langerak \& Hultink, 2006). Thus a process outcome of project speed reflects the time needed for projects to proceed through various phases of the NPD process (Griffin, 1993). Project speed, which incorporates the time it takes for a project to move from concept to market (Kessler \& Chakrabarti, 1996), also is key to managing the product portfolio, because it ensures a consistently scheduled stream of new products (Griffin, 1997). Firms seek to implement various techniques, management processes, and development strategies (Griffin, 1993) so that they can decrease cycle time and increase speed. Speeding up operations also provides firms with a competitive advantage and increases profits and market share (Kessler \& Chakrabarti, 1996). Such firm assets can provide an advantage, in terms of speeding up the NPD process (Sanchez \& Perez, 2003), while also lowering costs. Despite some mixed results with respect to speed and profitability (Langerak \& Hultink, 2006), a recent study affirms that speed positively effects profitability (McNally, Akdeniz, \& Calantone, 2011). We thus consider speed an important indicator of success.

\subsection{Resources}

Resources are the stocks, assets, and capabilities owned and controlled by a firm, which managers must identify, develop, protect, and deploy (Amit \& Schoemaker, 1993) to gain competitive advantages. Because firm 
resources can take many forms within an organization (Day, 1994), it is essential to identify the resources that are most pertinent to a specific product development project and assess their availability for use in NPD. The three resource characteristics and capabilities that we incorporate in our framework are resource flexibility, resource augmentation, and resource leveraging. They have not been studied together before in the context of NPD process outcomes.

Flexibility, or the ability of a firm to change direction quickly at low costs (Barney, 2002), is a characteristic with great importance (Wright \& Snell, 1998), especially to large technology firms and entrepreneurial startups (Evans, 1991). One type of flexibility is strategic flexibility, or a firm's ability to respond to uncertainty in its environment by exploiting its flexible resource base in response to alternative courses of action (Sanchez, 1995). Flexibility can help firms achieve their goals in uncertain environments (Al-jawazneh, 2012), and because it depends on available firm resources (Johnson et al., 2003), it can enable the firm to generate options for differentiated operations, if the need arises (Evans, 1991). A firm controls a flexible resource base if multiple strategic options are available for its use (Uhlenbruck, Meyer, \& Hitt, 2003). Flexible resources also can be useful for developing important NPD capabilities (Swan, Kotabe, \& Allred, 2005), which likely apply to more than one product (Chatterjee \& Wernerfelt, 1988).

Resource flexibility depends on usage (Sanchez, 1995), in the sense that it increases when more alternatives or options are readily available for using a particular resource. Thus switching costs, time required to switch, and the difficulty of switching should be lower than they would be with an inflexible resource base. Resources and capabilities that are too rigid or overly specialized may impede the firm's ability to seek other options (Teng \& Cummings, 2002). Because managers compete for access to limited resources for various projects and applications (Mizik \& Jacobson, 2003), flexible resources likely are more cost effective, because they can be deployed more readily than rigid resources. Project speed also should improve with resource flexibility, because it provides means to reconfigure the resource quickly. Similarly, costs should decrease, due to the projected ease of deploying a particular resource, together with the lower projected switching costs for its use.

$\mathrm{H}_{1}$ : Resource flexibility enhances new product outcomes by decreasing new product costs and improving new product speed.

Resource augmentation, or the process of enhancing a resource base by gathering additional resources and building on existing ones, is similar to the centrifugal force discussed by Sheremata (2000), such that a firm works to gather ideas, knowledge, and information to use in its creative actions. Resource augmentation research parallels literature on strategic intent, which pertains to the process and desire to succeed (Hamel \& Prahalad, 1989). That is, strategic intent leads an organization whose capabilities are insufficient to develop and accumulate additional resources, in pursuit of success. Through resource augmentation, managers assess the stocks available to the firm and increase the resource base before it is needed. Over time, this increase of assets should offset the depreciation or maintenance costs of assets, causing the asset base to grow overall (Dierickx \& Cool, 1989).

The advantages of building the resource base include two main abilities: to maintain the development of intellectual property within the boundaries of the firm and to incorporate resources that already are within the firm quickly. Firms with higher resource stock levels are less constrained by their resource base (Pecora \& Cesta, 2005) and should benefit from the NPD process, because their resource base already has been expanded and is available at the moment of need, before being incorporated into a specific NPD project. The accumulation of resources to assist in product development likely increases speed, because the resources are available when needed. This performance gain comes at a price though, in that the increased resources also increase the costs of product development.

$\mathrm{H}_{2}$ : Resource augmentation enhances new product outcomes by increasing product development speed but has a negative effect on development costs.

A resource bundle refers to a collection of resources that, when combined, can provide a firm with a competitive advantage (Barney, 1991); their interactions also may create new, intangible resources (Smith, Vasudevan, \& Tanniru, 1996). Although resource augmentation and flexibility add to the stocks and options needed to develop new products, they might not be sufficient to develop improved products. An often overlooked aspect of resource management is the recognition that simply controlling resources is not enough to achieve a satisfactory market position (Dierickx \& Cool, 1989). Resources, in and of themselves, are not strategically significant, nor are they adequate to create wealth. Thus, we must study what firms $d o$ with their resources (Calantone et al., 2010). That is, firms need to be innovative to take advantage of the limited number of resources available (Prahalad \& Hamel, 2005) and effectively use their resource stocks to their benefit. Therefore, we propose 
resource leveraging as a distinctive capability that a firm can use to gain a competitive advantage (Combs, Ketchen, Ireland, \& Webb, 2011; Sirmon \& Hitt, 2003).

The resource deployment capabilities of the firm involve resource leveraging; a firm must be able to configure and deploy its available resources (Johnson et al., 2003). Firms also can gain competitive advantages by seizing and capturing opportunities (Wilson \& Appiah-Kubi, 2002), such that they can enjoy positive new product outcomes if they effectively leverage their resources.

$\mathrm{H}_{3}$ : Resource leveraging enhances new product outcomes by decreasing new product costs and improving new product speed.

Resource leveraging also complements the allocation of resources, and firms can benefit from strategies that are less resource intensive (Hamel \& Prahalad, 1993). By effectively developing a flexible resource base and leveraging resources at will, they proceed faster, because of their ease of redeployment and the lower costs they attain from the more efficient use of resources. Similarly, expanding current resources might not be sufficient to gain a competitive advantage, and costs might continue to mount if they are not offset by usage efficiencies. Thus, we propose that resource augmentation supports quicker responses to changes in the environment, due to the increased availability of resources that it provides. Leveraging leads to cost improvements through more effective uses of the resource base. We therefore predict that resource leveraging acts as a moderator.

$\mathrm{H}_{4}$ : The more flexible resources and greater leveraging capability a firm has, the better the improvements in new product outcomes it attains by decreasing new product costs and improving new product speed.

$\mathrm{H}_{5}$ : The greater the augmentation and leveraging capabilities a firm has, the lower its costs and the greater its new product speed.

\section{Method}

The sampling frame was based on a list of industrial firms in the European Union; this list contained the names and contact data of key informants, who were all high ranking purchasing, supply chain, or operations managers. After cleaning the list by eliminating incomplete company or informant data, we sent e-mails to 729 firms, then followed up within a week. All participants had an opportunity to enter a prize raffle. We received 71 usable responses, for an overall response rate of $9.74 \%$.

The sample firms represented the machinery, automotive, construction, chemicals, high-tech, and other manufacturing industries. These firms employed anywhere from 6 to 360,000 personnel, with an average of 10,800 . We converted all monetary values into U.S. dollars, such that the annual sales for the sample firms ranged from $\$ 14,000$ to $\$ 145$ billion, with an average of $\$ 4$ billion. Annual purchasing volumes for the firms were as low as $\$ 6,000$ and as high as $\$ 45$ billion, with an average of $\$ 1.2$ billion. Informants were directors or vice presidents of purchasing (33.8\%), purchasing managers (23.9\%), directors or vice presidents of materials management $(21.2 \%)$, or supply chain managers $(21.1 \%)$, and a few held other managerial positions within the organization. To test for nonresponse bias, we compared early with late respondents on the basis of firm characteristics, such as number of employees, annual sales, purchasing volumes, supplier base, and model constructs. We found no differences, so we did not perceive a threat of nonresponse bias in the data.

\subsection{Measures}

To develop the survey instrument, we used existing scales and operationalizations of model constructs. The questionnaire was pretested in two phases. The first phase used a hard copy of the draft questionnaire, administered to four managers of different firms. We included feedback from these managers in a revised version of the questionnaire. The questionnaire also was checked for consistency, grammar, and spelling prior to developing the electronic version. In the second phase, we administered the electronic survey to the same four managers and asked them to comment on its functionality, consistency, and understanding, before we launched the large-scale administration. The construct items for all multi-item measures are in Table 1. 
Table 1. Items and multi-item construct properties

\begin{tabular}{|c|c|c|c|}
\hline & Loading & Mean & SD \\
\hline \multicolumn{4}{|l|}{ Resource Flexibility (Cronbach's alpha $=.804$, composite reliability $=.854$ ) } \\
\hline \multicolumn{4}{|l|}{ With respect to the resources our firm possesses, we... } \\
\hline have a large range of applications for our resources. & .678 & 3.54 & .825 \\
\hline can easily switch applications. & .800 & 3.30 & .991 \\
\hline can accommodate changes. & .873 & 3.92 & .751 \\
\hline can allow for options. & .722 & 3.66 & .955 \\
\hline \multicolumn{4}{|l|}{ Resource Augmentation (Cronbach's alpha $=.769$, composite reliability $=.815$ ) } \\
\hline \multicolumn{4}{|l|}{ For the products that your firm develops, to what extent do you consider that... } \\
\hline our firm effectively mixes and matches new technologies to extend our existing technologies. & .549 & 3.90 & 1.084 \\
\hline recently developed technologies by us are distinct and unique from our previous technologies. & .808 & 3.66 & 1.341 \\
\hline our recent intellectual property development has expanded the scope of our technologies. & .929 & 2.89 & 1.326 \\
\hline \multicolumn{4}{|l|}{ Resource Leveraging (Cronbach's alpha $=.890$, composite reliability $=.923$ ) } \\
\hline \multicolumn{4}{|l|}{ With respect to the resources our firm possesses, we are... } \\
\hline able to leverage resources. & .900 & 3.68 & .922 \\
\hline good at putting our resources where they work best. & .853 & 3.66 & .877 \\
\hline effective in optimizing on our resources. & .915 & 3.65 & .987 \\
\hline constantly trying to find new ways of exploiting our resources. & .791 & 4.04 & .901 \\
\hline \multicolumn{4}{|l|}{ Costs $($ Cronbach's alpha $=.635$, composite reliability $=.753)$} \\
\hline The development costs exceeded our budget (reverse coded). & 642 & 3.76 & 1.213 \\
\hline Relative to similar scale products we have developed in the past, the development costs were less. & .716 & 2.93 & 1.046 \\
\hline The commercialization costs exceeded budget (reverse coded). & 622 & 4.13 & 1.027 \\
\hline $\begin{array}{l}\text { Relative to similar scale products we have developed in the past, the commercialization costs } \\
\text { were less. }\end{array}$ & .755 & 3.01 & 1.076 \\
\hline \multicolumn{4}{|l|}{ Speed $($ Cronbach's alpha $=.728$, composite reliability $=.845)$} \\
\hline \multicolumn{4}{|l|}{$\begin{array}{l}\text { With regard to the product development project with contribution from SUPPLIER X, please rate } \\
\text { the following statements: }\end{array}$} \\
\hline $\begin{array}{l}\text { This project took longer than the usual amount of time for a project like this in our firm (reverse } \\
\text { coded). }\end{array}$ & .734 & 3.94 & 1.157 \\
\hline My firm holds this project up as an example of fast product development. & .866 & 3.38 & 1.211 \\
\hline This was one of the fastest projects ever undertaken by this organization. & .805 & 2.28 & 1.267 \\
\hline
\end{tabular}

${ }^{\circ}$ Likert-type measurement scale ( 1 = "strongly disagree," 5 = "strongly agree").

Conceptual investigations of the use-based view of resources (Sanchez, 1995) provided the foundation for our approach to resource flexibility. Consistent with common views on flexibility, we assessed it over time, to support comparisons (Wright \& Snell, 1998). Next, we developed a four-item scale to measure the range of options, switching ability, and options each firm had available. For resource augmentation, we measured the extent to which a firm used technology and intellectual property to extend its NPD abilities. With a three-item scale, we determined the degree to which the firm differentiated itself from its competitors using its technology and intellectual property base. Resource leveraging was represented by the process of developing and adapting company resources to exploit opportunities (Hamel \& Prahalad, 1995), including using existing resources creatively and effectively to achieve challenging goals (Zahra, Matherne, \& Carleton, 2003). We developed a four-item scale for this construct.

Following Griffin (1993), we employed several outcome measures at the project level. The advantage of using a project as a unit of analysis, compared with other units of analysis such as business units, is that projects can be monitored more readily for speed and costs (Kessler \& Chakrabarti, 1999). Similar to research that evaluates project costs (e.g., Langerak, Griffin, \& Hultink, 2010), we developed a four-item scale to measure relative cost performance.

Project speed represents the time it takes for a project to be developed (Kessler \& Bierly, 2002) and operationalized, according to the product development time (Griffin, 1993). To measure this construct, we used relative, rather than objective, measures, because we sought to identify efficiency differences in product 
development time. Similar to project costs, relative measures are preferable for speed, because they facilitate comparisons across projects and correlate with objective measures. The use of relative measures, which are easier to obtain than objective measures, also is consistent with prior research (Langerak \& Hultink, 2006). By basing our construct on relative measures, we could account for differences in projects among firms. We adapted this scale from prior research (Akgün \& Lynn, 2002) and used a three-item scale.

Because firm size has a positive effect on new product performance (Gatignon \& Xuereb, 1997), we included two size measures as control variables: (1) annual sales, to address firm-specific effects, and (2) the number of firm employees, as a proxy for firm size. We used log functions of both measures.

\subsection{Measure Validation}

The composite reliability for each construct appears in Table 1 . The lowest calculated composite reliability was 0.753 for the cost construct. Because this value exceeded the .7 criterion, we retained it as a new product outcome variable. Using the average variance extracted (AVE) and correlation matrix (Table 2), we evaluated the convergent and divergent validity. All the AVE values except for the cost construct were greater than .50. We assessed the item loadings for the cost construct further; the lowest loading was .622, and the construct's composite reliability equaled .753, so we determined it was appropriate to include in the model. In support of the discriminant validity of all constructs, the square root of the AVE value for each construct was greater than the correlation between the construct and any other construct (Fornell \& Larcker, 1981).

Table 2. Correlations of constructs and square root of average variance extracted

\begin{tabular}{|c|c|c|c|c|c|c|c|}
\hline & 1 & 2 & 3 & 4 & 5 & 6 & 7 \\
\hline $\begin{array}{l}\text { 1.Resource } \\
\text { flexibility }\end{array}$ & .772 & & & & & & \\
\hline $\begin{array}{l}\text { 2.Resource } \\
\text { augmentation }\end{array}$ & $.206^{*}$ & .778 & & & & & \\
\hline $\begin{array}{l}\text { 3.Resource } \\
\text { leveraging }\end{array}$ & $.347 * *$ & $.209 *$ & .865 & & & & \\
\hline 4.Decreased costs & -.056 & $-.214 *$ & .139 & .686 & & & \\
\hline 5.Increased speed & .165 & $.232 *$ & $.397 * *$ & .160 & .803 & & \\
\hline 6. log Sales & $.221 *$ & .145 & .127 & .154 & .026 & - & \\
\hline 7. log Employees & $.225 *$ & $.216^{*}$ & .123 & .164 & -.009 & $.743 * *$ & - \\
\hline Mean & 3.561 & 3.484 & 3.757 & 3.458 & 3.202 & 8.080 & 2.715 \\
\hline SD & .964 & 1.036 & .800 & .755 & .975 & 1.086 & .956 \\
\hline
\end{tabular}

${ }^{0}$ Diagonal contain the square root of AVE. ${ }^{*} p<.05$ level (two-tailed). ${ }^{* *} p<.01$ level (two-tailed).

\subsection{Data Analysis}

To test the research hypotheses, we used partial least squares (PLS) with bootstrapping, a useful method of analysis because it places minimal demands on the measurement scales, sample size, or residual distributions. Using PLS, we considered all path coefficients simultaneously while estimating the individual item loadings to obtain a model that contained unbiased and consistent estimators (Hair, Hult, Ringle, \& Sarstedt, 2013).

\section{Results}

We investigated the structural model using path estimates calculated in PLS. In addition to testing the main effects, we considered a set of interactions, based on characteristics and capabilities, which we included in the analysis. A summary of the paths for both models appears in Table 3, along with both outcome measures run simultaneously. We followed the procedure set forth by Chin, Marcolin, and Newsted (2003) to test the interactions, such that we included the main effects and interaction terms simultaneously. The path estimates for each outcome were listed separately, with appropriate R-square values for each dependent construct. The R-squares for the new product outcomes of decreased costs and increased speed were .280 and .115 , respectively. 
Table 3. Path estimates of PLS model

\begin{tabular}{|c|c|c|c|c|}
\hline \multirow[b]{2}{*}{ Sales } & \multicolumn{2}{|c|}{ Decreased Costs } & \multicolumn{2}{|c|}{ Increased Speed } \\
\hline & .078 & $(.585)$ & .009 & $(.315)$ \\
\hline Employees & .096 & $(.607)$ & -.017 & $(.326)$ \\
\hline Resource flexibility & .002 & $(.483)$ & .126 & $(.432)$ \\
\hline Resource augmentation & -.275 & $(.206)^{*}$ & .774 & $(.198)^{* * *}$ \\
\hline Resource leveraging & .051 & $(.150)$ & .221 & $(.139)^{*}$ \\
\hline Resource flexibility $\times$ Resource leveraging & -.329 & $(.681)$ & -.066 & $(.606)$ \\
\hline Resource augmentation $\times$ Resource leveraging & .617 & $(.468)^{*}$ & .562 & $(.430)^{*}$ \\
\hline $\boldsymbol{R}^{2}$ & .280 & & .115 & \\
\hline
\end{tabular}

${ }^{\ominus}$ Standard error in parentheses. ${ }^{*} p<.10 . * * p<.01$.

In turn, we found support for some of the proposed relationships, though not the hypothesized link between resource flexibility and performance. In line with $\mathrm{H}_{2}$, resource augmentation as a firm capability led to increased $\operatorname{costs}(\gamma=-.275 ; p<.10)$ and increased product development speed $(\gamma=.774, p<.01)$. Although leveraging did not lower costs, it increased development speed $(\gamma=.221, p<.10)$, resulting in partial support for $\mathrm{H}_{3}$. We could not confirm $\mathrm{H}_{4}$, because resource leveraging did not moderate the flexibility-performance link. The predicted role of leveraging as a moderator of the augmentation-performance link received support, due to the decrease in costs $(\gamma=.617, p<.10)$ and increase in speed $(\gamma=.562, p<.10)$, in line with $\mathrm{H}_{5}$. With this support, we can conclude partial support for resource leveraging as a moderator of the performance link.

\section{Discussion}

We have explored the effects of resource and capability characteristics on new product outcomes and extended research on flexibility by integrating resource leveraging; leveraging can moderate the relationship between flexibility and NPD performance. These findings offer exciting results pertaining to resource characteristics and capabilities, for both researchers and practitioners, as they relate to NPD processes.

Because NPD often involves problem-solving processes (Sheremata, 2000), resource flexibility should enhance the NPD process by increasing the number of options available for applying resources when needed. With regard to the effect of resource flexibility, our results do not indicate benefits of reduced costs or increased speed though, which suggests that resources with several uses might not have process cost advantages or increase product development speed. Consistent with our hypotheses, our resource augmentation results instead suggest that though firms experience a cost disadvantage while accruing resources, they may be able to improve product development speed, because their resources are more accessible and can be deployed more readily. Because resource augmentation is often directed by managers, who aim to develop and expand their existing resource bases, it requires managers to pursue a focused path to augment the resource base and develop products quickly. The expansion of the resource base comes at a price to the firm, consistent with Kessler and Bierly's (2002) suggestion that a speed-based strategy is costly because of the additional resources needed to gain development speed. Resource leveraging had no effect on costs other than improved development speed; that is, firms developing new products can attain development speed improvements if they can maximize the efficiency of the resources to which they already have access.

Even if resource flexibility and augmentation provide value to firms for their product development, it is the presence of resource leveraging that actually leads to enhanced performance. We do not find support for a role of resource leveraging in the flexibility-performance link, but we confirm that leveraging moderates the augmentation-performance link. Firms with the ability to accrue resources enjoy decreased product development costs and improved product development speed - if they can manage to leverage their resource bases. This abundance of options could be problematic for managers who need to find quick solutions to challenges in the development process though, so the ability to maximize the usefulness of the resource base enables firms to decrease, rather than increase, their development costs.

Our results also highlight two important findings. Previous research cites the benefits of resource flexibility and of accumulating a large resource base; our findings suggest that resource flexibility might not lead to performance gains and that its accumulation increases costs. Our first finding shows that resource leveraging improves the benefits of accumulating resources by improving usage efficiency, which leads to performance gains. Unfortunately, our findings do not indicate any moderation of the flexibility-NPD performance link, so managers might need to emphasize capabilities other than flexibility to maximize their performance gains. 
In addition, because the NPD process can be modeled with coexisting, contradictory elements (Sheremata, 2000), it is plausible that resources and capabilities have differential performance outcomes. Similarly, in their study of strategic orientation and organizational capability, Kessler and Chakrabarti (1999) find that some factors have different levels of influence on innovation speed. Thus managers must monitor project speed, because time-to-market is critical to the success of products, and costs affect breakeven points. Project speed is increasingly important to firms in many competitive industries; we find that resource augmentation and resource leveraging relate positively to speed. Our results thus support the notion of differential effects, such that resource augmentation leads to improved product development speed while decreasing cost performance (i.e., increased product development costs). Managing speed in turbulent markets is truly significant to firms developing new products (Calantone, Rosanna, \& Droge, 2003), and managers who face such environments may focus on resource augmentation to respond to changes in the dynamic market. But they also need to realize that this accrual of resources will increase their costs. If managers focus only on one process outcome, they should tailor their resource management to meet certain process objectives. Managers directed to improve several objectives simultaneously could face the challenging task of seeking other characteristics and capabilities to meet their target objectives. Our analysis notes that firms can decrease costs by either decreasing resource augmentation or leveraging accumulated resource bases. The reduction in resource augmentation may seem counterintuitive, but because the development of intellectual property (e.g., patents, process-specific technology) takes time, costs increase as these types of resources get developed.

A few aspects of this endeavor also should be highlighted, prior to generalizing the findings to other populations. First, we selected particular resource capabilities, but other capabilities also could enhance cost reduction while improving product development speed. Second, we used perceptual measures for performance. An extension of this research might consider secondary measures of performance to confirm whether these relationships match other performance measures. Third, we note potential concerns about the small sample size. Although we used PLS with bootstrapping, we included only 71 firms in our sample. Further research should seek a larger sample and seek to replicate our results. Fourth, the survey instrument underwent a rigorous translation process, but there might have been some subtle differences between the two versions of the instrument.

\section{References}

Akgün A. E., \& Lynn, G. S. (2002). New product development team improvisation and speed-to-market: An extended model. European Journal of Innovation Management, 5(3), 117-129. http://dx.doi.org/10.1108/14601060210436709

Al-jawazneh, B. E. (2012). Manufacturing flexibility and operational performance of Pharmaceutical Manufacturing companies in Jordan. International Journal of Business and Management, 7(4), 181-194. http://dx.doi.org/10.5539/ijbm.v7n4p181

Amit, R., \& Schoemaker, P. J. H. (1993). Strategic assets and organizational rent. Strategic Management Journal, 14(1), 33-46. http://dx.doi.org/10.1002/smj.4250140105

Barney, J. B. (1991). Firm resources and sustained competitive advantage. Journal of Management, 17(1), 99-120. http://dx.doi.org/10.1177/014920639101700108

Barney, J. B. (2002). Gaining and sustaining competitive advantage. Upper Saddle River, NJ: Prentice Hall.

Bayus, B. L. (1997). Speed-to-market and new product performance trade-offs. Journal of Product Innovation Management, 14(6), 485-497. http://dx.doi.org/10.1111/1540-5885.1460485

Calantone, R. J., Harmancioglu, N., \& Droge, C. (2010). Inconclusive innovation 'returns': A meta-analysis of research on innovation in new product development. Journal of Product Innovation and Management, 27(7), 1065-1081. http://dx.doi.org/10.1111/j.1540-5885.2010.00771.x

Calantone, R. J., Rosanna, G., \& Droge, C. (2003). The effects of environmental turbulence on new product development strategy planning. Journal of Product Innovation Management, 20(2), 90-103. $\mathrm{http}: / / \mathrm{dx}$.doi.org/10.1111/1540-5885.2002003

Chatterjee, S., \& Wernerfelt, B. (1988). Related or unrelated diversification: A resource based approach. Academy of Management Best Paper Proceedings, 7-11. http://dx.doi.org/10.5465/AMBPP.1988.4979378

Chin, W. W., Marcolin, B. L., \& Newsted, P. R. (2003). A partial least squares latent variable modeling approach for measuring interaction effects: Results from a Monte Carlo simulation study and an electronic-mail emotion/adoption study. Information Systems Research, 14(2), 189-217. http://dx.doi.org/10.1287/isre.14.2.189.16018 
Combs, J. G., Ketchen, D. J., Ireland, D., \& Webb, J. W. (2011). The role of resource flexibility in leveraging strategic resources. Journal of Management Studies, 48(5), 1098-1125. http://dx.doi.org/10.1111/j.1467-6486.2009.00912.x

Day, G. S. (1994). The capabilities of market-driven organizations. Journal of Marketing, 58(4), 37-52. http://dx.doi.org/10.2307/1251915

Dierickx, I., \& Cool, K. (1989). Asset stock accumulation and sustainability of competitive advantage. Management Science, 35(12), 1504-1511. http://dx.doi.org/10.1287/mnsc.35.12.1504

Ersun, A. N., \& Karabulut, A. T. (2013). Innovation management and marketing in global enterprises. International Journal of Business and Management, 8(20), 76-86. http://dx.doi.org/10.5539/ijbm.v8n20p76

Evans, J. S. (1991). Strategic flexibility for high technology manoeuvres: A conceptual framework. Journal of Management Studies, 28(1), 69-87. http://dx.doi.org/10.1111/j.1467-6486.1991.tb00271.x

Fornell, C., \& Larcker, D. F. (1981). Structural equation models with unobservable variables and measurement error: Algebra and statistics. Journal of Marketing Research, 18(3), 382-388. http://dx.doi.org/10.2307/3150980

Gatignon, H., \& Xuereb, J. (1997). Strategic orientation of the firm and new product performance. Journal of Marketing Research, 34(1), 77-90. http://dx.doi.org/10.2307/3152066

Griffin, A. (1993). Metrics for measuring product development cycle time. Journal of Product and Innovation Management, 10(2), 112-125. http://dx.doi.org/10.1111/1540-5885.1020112

Griffin, A. (1997). The effect of project and process characteristics on product development cycle time. Journal of Marketing Research, 34(1), 24-35. http://dx.doi.org/10.2307/3152062

Hair, J. F., Hult, G. T. M., Ringle, C. M., \& Sarstedt, M. (2013). A primer on partial least squares structural equation modeling (PLS-SEM). Thousand Oaks, CA: Sage.

Hamel, G., \& Prahalad, C. K. (1989). Strategic intent. Harvard Business Review, 67(3), 73-79.

Hamel, G., \& Prahalad, C. K. (1993). Strategy as a stretch and leverage. Harvard Business Review, 71(2), 75-84.

Hamel, G., \& Prahalad, C. K. (1995). Seeing the future first. Executive Excellence, 12(11), 15-16.

Hamel, G., \& Prahalad, C. K. (2005). Strategic intent. Harvard Business Review, 83(7), 148-161.

Henard, D. H., \& Szymanski, D. M. (2001). Why some new products are more successful than others. Journal of Marketing Research, 38(3), 362-375. http://dx.doi.org/10.1509/jmkr.38.3.362.18861

Hsu, Y. (2011). Design innovation and marketing strategy in successful product competition. Journal of Business \& Industrial Marketing, 26(4), 223-236. http://dx.doi.org/10.1108/08858621111126974

Johnson, J. L., Lee, R. P. W, Saini, A., \& Grohmann, B. (2003). Market-focused strategic flexibility: Conceptual advances and an integrative model. Journal of the Academy of Marketing Science, 31(1), 74-89. http://dx.doi.org/10.1177/0092070302238603

Kandemir, D., Calantone, R. J., \& Garcia, R. (2006). An exploration of organizational factors in new product development success. Journal of Business \& Industrial Marketing, 21(5), 300-310. http://dx.doi.org/10.1108/08858620610681605

Kessler, E. H., \& Bierly, P. E. (2002). Is faster really better? An empirical test of the implications of innovation speed. IEEE Transactions on Engineering Management, 49(1), 2-12. http://dx.doi.org/10.1109/17.985742

Kessler, E. H., \& Chakrabarti, A. K. (1996). Innovation speed: A conceptual model of context, antecedents, and outcomes. Academy of Management Review, 21(4), 1143-1191. http://dx.doi.org/10.5465/amr.1996.9704071866

Kessler, E. H., \& Chakrabarti, A. K. (1999). Speeding up the pace of new product development. Journal of Product and Innovation Management, 16(3), 231-247. http://dx.doi.org/10.1111/1540-5885.1630231

Langerak, F., Griffin, A., \& Hultink, E. J. (2010). Balancing development costs and sales to optimize the development time of product line additions. Journal of Product Innovation Management, 27(3), 336-348. http://dx.doi.org/10.1111/j.1540-5885.2010.00720.x 
Langerak, F., \& Hultink, E. J. (2006). The impact of product innovativeness on the link between development speed and new product profitability. Journal of Product Innovation Management, 23(3), 203-214. http://dx.doi.org/10.1111/j.1540-5885.2006.00194.x

McNally, R. C., Akdeniz, M. B., \& Calantone, R. J. (2011). New product development processes and new product profitability: Exploring the mediating role of speed to market and product quality. Journal of Product Innovation Management, 28(1), 63-77. http://dx.doi.org/10.1111/j.1540-5885.2011.00861.x

Mizik, N., \& Jacobson, R. (2003). Trading off between value creation and value appropriation: The financial implications of shifts in strategic emphasis. Journal of Marketing, 67(1), 63-76. http://dx.doi.org/10.1509/jmkg.67.1.63.18595

Montoya-Weiss, M. M., \& Calantone, R.J. (1994). Determinants of new product performance: A review and meta-analysis. Journal of Product and Innovation Management, 11(5), 397-417. http://dx.doi.org/10.1016/0737-6782(94)90029-9

Pecora, F., \& Cesta, A. (2005). Evaluating plans through restrictiveness and resource strength. Institute for Cognitive Science and Technology, Italian Research Council.

Rumelt, R. P. (1987). Towards a strategic theory of the firm. In R.B. Lamb (Ed.), Competitive strategic management (pp. 556-570). Englewood Cliffs, NJ: Prentice Hall.

Sanchez, R. (1995). Strategic flexibility in product competition. Strategic Management Journal, 16(1), 135-159. http://dx.doi.org/10.1002/smj.4250160921

Sanchez, A. M., \& Perez, M. P. (2003). Cooperation and the ability to minimize the time and cost of new product development within the Spanish automotive supplier industry. Journal of Product and Innovation Management, 20(1), 57-69. http://dx.doi.org/10.1016/0024-6301(95)99971-2

Schmidt, J. B., \& Calantone, R. J. (2002). Escalation of commitment during new product development. Journal of the Academy of Marketing Science, 30(2), 103-118. http://dx.doi.org/10.1177/03079459994362

Sheremata, W. A. (2000). Centrifugal and centripetal forces in radical new product development under time pressure. Academy of Management Review, 25(2), 389-408. http://dx.doi.org/10.5465/amr.2000.3312925

Sirmon, D. G., \& Hitt, M. A. (2003). Managing resources: Linking unique resources, management, and wealth creation in family firms. Entrepreneurship Theory and Practice, 27(4), 339-358. http://dx.doi.org/10.1111/1540-8520.t01-1-00013

Smith, K. A., Vasudevan, S. P., \& Tanniru, M. R. (1996). Organizational learning and resource-based theory: An integrative model. Journal of Organizational Change Management, 9(6), 41-53. http://dx.doi.org/10.1108/09534819610150512

Swan, K. S., Kotabe, M., \& Allred, B. B. (2005). Exploring robust design capabilities, their role in creating global products, and their relationship to firm performance. Journal of Product Innovation Management, 22(2), 144-164. http://dx.doi.org/10.1111/j.0737-6782.2005.00111.x

Teng, B. S., \& Cummings, J. L. (2002). Trade-offs in managing resources and capabilities. Academy of Management Executive, 16(2), 81-91. http://dx.doi.org/10.5465/ame.2002.7173548

Uhlenbruck, K., Meyer, K. E., \& Hitt, M. A. (2003). Organizational transformation in transition economies: Resource-based and organizational learning perspectives. Journal of Management Studies, 40(2), 257-282. http://dx.doi.org/10.1111/1467-6486.00340

Wilson, H. I. M., \& Appiah-Kubi, K. (2002). Resource leveraging via networks by high-technology entrepreneurial firms. Journal of High Technology Management Research, 13(1), 45-62. http://dx.doi.org/10.1016/s1047-8310(01)00048-7

Wright, P. M., \& Snell, S. A. (1998). Toward a unifying framework for exploring fit and flexibility in strategic human resource management. Academy of Management Review, 23(4), 756-772. http://dx.doi.org/10.5465/amr.1998.1255637

Zahra, S. A., Matherne, B. A., \& Carleton, J. M. (2003). Technological resource leveraging and the internationalisation of new ventures. Journal of International Entrepreneurship, 1(2), 163-186. http://dx.doi.org/10.1023/A:1023852201406 


\section{Copyrights}

Copyright for this article is retained by the author(s), with first publication rights granted to the journal.

This is an open-access article distributed under the terms and conditions of the Creative Commons Attribution license (http://creativecommons.org/licenses/by/3.0/). 